enforcement in Ukraine: unresolved issues. Arkhivy Ukrainy, 1/2, 11-20 [in Ukrainian].

14. Kyselova, L. (2012). Defining European standards in the field of archival and record keeping. Derzhavne Upravlinnia Ta Mistseve Samovriaduvannia, 4, 142-150 [in Ukrainian].

15. Matiash, Y. B., Khrystova, N. N. (2006). Standardization of Documentation Technologies in Ukraine. Dokumentatsyia v informatsyonnom Obshchestve. Moscow, 304-306 [in Russian].

16. International Descriptive Standards ISAD (G), ISAAR (CPF), ISDIAH, ISDF, EAD, EAC and Problems of their Implementation in the Ukrainian Archives (2009) : Analit. Ohliad, P. M. Marchenko, N. M. Khrystova; Derzhkomarkhiv Ukrainy, UNDIASD. Kyiv [in Ukrainian].

17. Tur, O. M. (2011). International and foreign standards for information and documentation as a factor in the development of the national standardization process. Dokumentoznavstvo. Bibliotekoznavstvo. Informatsiina Diialnist, Kyiv, 15-17 [in Ukrainian].

18. Kharchenko, S. V., Lytvynska, S. V. (2013). Problematic aspects of the functioning of national standards of the Information and Documentation series. Bibliotekoznavstvo. Dokumentoznavstvo. Informolohiia, 1, 8-16 [in Ukrainian].

19. Khramtsovskaia, N. A. (2009). New international and national standards in the field of documentation management. Sekretar-Referent, 6, 32-37 [in Russian].

УДК 81.322

Лукаш Галина Павлівна,

доктор філологічних наук, професор,

професор кафедри інформаційних систем управління

Донецького національного університету імені Василя Стуса

g.lukash@donnu.edu.ua

https://orcid.org/0000-0002-9777-7718

\title{
КАТЕГОРІАЛЬНІ ПАРАДИГМИ ТЕКСТУ ДОКУМЕНТА
}

Метароботи-охарактеризуватитекст документа через системудиспозиційпарадигмкатегорій як когнітивної моделі у контексті документної лінгвістики. Методологія дослідження полягає у використанні загальнонаукових методів аналізу, синтезу, а також системного, структурного та діалектичного. Діалектичний метод вимагає розгляду текстових категорій у їхньому безперервному русі, взаємозв'язках $і$ взаємозалежності. Системний метод передбачає пошук $і$ визначення таких сукупностей пізнавальних процесів, які тісно взаємопов'язані та утворюють під час сприймання тексту певну иілісність, єдність. Структурний метод як невід'ємна складова системного сприяє характеристичі стійких зв'язків категорій тексту. Наукова новизна роботи полягає в аналізі прочесу категоризаиії дійсності, внаслідок якого мовні категорії документного тексту постають як когнітивні утворення. Носіїмови, узагальнюючи ситуаџї сприйняття, уявлення, мислення, комунікаиї, дії, втілюють їх у формі пізнавальної категоріальної сітки. Запропоновано виділити нову категорію документного тексту та ії субкатегорії, досі не описану у документній лінгвістиці,-категорію якості. Якість характеризується як один з пріоритетних щаблів у системі пізнання і поєднує в собі здатність вирізняти об'єкт з-поміж інших, характеризувати його зовнішні та внутрішні властивості. Такий підхід знімає невизначеність у розуміння ознак тексту та його категорій. Висновки. Спостереження над змістовими іформальними категоріямита параметрамитекстудокумента свідчитьпроте, щоцей текст має свій категоріальний каркас іє осередком організованого, упорядкованого, запрограмованого акту комунікаиії в його прагматичній спрямованості. Подібно рівневим одинииям мови, категорії тексту є знаковими утвореннями. План змісту такого знака - ие та чи інша понятійна універсалія, спільна в цілому тексті семантика, а план вираження - точний добір різних мовних засобів.

Ключові слова: парадигма, текст документа, мовні категорії, категорія якості, субкатегорії, документна лінгвістика. 
Лукаш Галина Павловна,

доктор филологических наук, профессор, профессор кафедры информационных систем управления Донецкого национального университета имени Василия Стуса

\section{КАТЕГОРИАЛЬНЫЕ ПАРАДИГМЫ ТЕКСТА ДОКУМЕНТА}

Цель работы - охарактеризовать текст документа через систему диспозиций парадигм категорий как когнитивноймоделив контексте документнойлингвистики. Методология исследования заключается в использовании общенаучных методов анализа, синтеза, а также системного, структурного и диалектического. Диалектический метод требует рассмотрения текстовых категорий в их непрерывном движении, взаимосвязях и взаимозависимости. Системный метод предусматривает поиск и определение таких совокупностей познавательных процессов, которые тесно взаимосвязаны и образуют во время восприятия текста определенную иелостность, единство. Структурный метод как неотъемлемая составляющая системного способствует характеристике устойчивых связей категорий текста. Научная новизна работы заключается в анализе прочесса категоризации действительности, в результате которого языковые категории документационного текста предстают как когнитивные образования. Носители языка, обобщая ситуации восприятия, представления, мышления, коммуникаиии, действия, воплощяают их в форме познавательной категориальной сетки. Предложено выделить новую категорию документационного текста (и его субкатегории), до сих пор не описанную в документных лингвистике, - категорию качества. Качество характеризуется как одна из приоритетных ступеней в системе познания и сочетает в себе способность выделять объект среди других, характеризовать его внешние и внутренние свойства. Такой подход снимает неопределенность в понимание признаков текста и его категорий. Выводы. Наблюдения над содержательными и формальными категориями и параметрами текста документа свидетельствует о том, что этот текст имеет свой категориальный каркас и является центром организованного, упорядоченного, запрограммированного акта коммуникации в его прагматической направленности. Подобно уровневым единицам языка, категории текста являются знаковыми образованиями. План содержания такого знака - это та или иная понятийная универсалия, общая в целом тексте семантика, а план выражения - точный подбор различных языковых средств.

Ключевые слова: парадигма, текст документа, языковые категории, категория качества, субкатегории, документная лингвистика.

Lukash Halyna,

Doctor of Philology, Professor, Department of Management Information Systems Vasyl' Stus Donetsk National University

\section{CATEGORIAL PARADIGMS OF THE DOCUMENT TEXT}

The purpose of the article is to characterize the text of the document through the system of dispositions of category paradigms as a cognitive model in the context of documentary linguistics. The methodology of the study is the use of general scientific methods of analysis, synthesis, as well as systemic, structural, and dialectical. The dialectical method requires consideration of the text categories in their continuous motion, interconnections, and interdependencies. The systematic approach involves searching for and defining such sets of cognitive processes that are closely interrelated and, when perceiving the text, have a certain integrity and unity. The structural method as an integral part of the system contributes to the characterization of stable links of categories of text. The scientific novelty of the work lies in the analysis of the process of categorization of reality, as a result of which the linguistic categories of document text appear as cognitive formations. Speakers of language, generalizing situations of perception, imagination, thinking, communication, action, embody them in the form of a categorical cognitive grid. It is proposed to highlight a new category of document text not yet described in document linguistics, the quality category. Quality is characterized as one of the priority steps in the cognition system and combines the ability to distinguish an object from among others, to characterize its external and internal properties. This approach eliminates ambiguity in understanding the 
features of the text and its categories. Conclusions. Observation of the substantive and formal categories and parameters of the text of the document indicates that this text has a categorical framework and is the focus of an organized, ordered, programmed act of communication in its pragmatic orientation. Like level units of language, text categories are symbolic entities. The content plan of such a sign is one or another conceptual universality, universal throughout the text of semantics, and the expression plan is an exact selection of different linguistic means.

Keywords: paradigm, document text, language categories, category of quality, subcategories, documentary linguistics.

Актуальність теми дослідження. Документна лінгвістика - теоретико-практичний розділ мовознавства, специфіка якого визначається багатьма чинниками. Один з них - тісний зв'язок із документознавством, науковопрактичним напрямом, що має потужний вплив на мову механізмів уніфікації та класифікації. До того ж, документна лінгвістика досліджує одиниці, правила побудови та умови функціонування лінгвістично однорідних об'єктів документних текстів. Науково-технічний прогрес, розвиток й інтеграція наукових знань у мовознавстві і документознавстві, потреба в удосконаленні організації змісту документа, уніфікації його інформаційної частини актуалізували вивчення внутрішньої структури тексту службового документа, його змістових та формальних категорій і субкатегорій.

Аналіз досліджень і публікацій. Поняття «текстова категорія» у лінгвістику тексту увійшло вже в середині 70-х років минулого століття, проте до цього часу чітко не визначене. Частково це пов'язано з тим, що нерідко категоріями називають ознаки, тому і в роботах 3 теорії тексту ці терміни слугують однотипними характеристиками тексту, а в одних дослідженнях належать до його ознак, в інших - до категорій [1, с. 7]. Спроби систематизувати категорії тексту ні до чого не призвели, тому що до цього часу критерії розмежування категоріальних і некатегоріальних ознак тексту остаточно не вироблені. Ця проблема посідає важливе місце в роботах як вітчизняних, так i зарубіжних лінгвістів: І.Р. Гальперіна, 3.Я. Тураєва, О.П. Воробйової, В.А. Лукіна, А.А. Леонтьєва та ін. [8, с. 131]. В українському мовознавстві лінгвістика тексту була спрямована здебільшого в практичне русло, розв'язуючи проблеми правильної організації зв'язного мовлення, семантики художніх текстів тощо. Останнім часом цій науці намагаються надати теоретичного спрямування [5, с.12]. Переважно саме у практичному спрямуванні теорія тексту увійшла і до документної лінгвістики.

Мета дослідження. Метою нашої розвідки стала спроба здійснити категоріальну характеристику тексту документа через систему диспозицій парадигм як моделі постановки проблем і прийомів рішень у контексті документної лінгвістики.

Виклад основного матеріалу. Категоризація - об'єкт дослідження усіх наук, які так чи інакше пов'язані із вивченням людського пізнання: психології, лінгвістики, культурології, тощо. Так, Н. Рябцева відзначає: «Категоризація - найважливіша інтелектуальна операція, яку людина виконує постійно і в усіх видах діяльності, підсвідомо категоризуючи усе, із чим стикається, про що думає, на що спрямовує свої зусилля» [цит. за: 6]. Дж. Брунер, класик когнітивної психології, аналізуючи процес сприйняття, відзначив, що якби якесь сприйняття виявилося не включеним до системи категорій, тобто вільним від віднесення до системи категорій, воно було б приречене залишатися недоступною перлиною, жарптицею, похованою у німоті індивідуального досвіду [3, с. 17].

У процесі категоризації відбувається виділення об'єкта з інформаційного потоку на підставі віднесення його до певного класу. Людина поділяє потік інформації на дискретні значущі одиниці, що дозволяє орієнтуватися у світі і надати дійсності якусь певну часову стабільність, структурованість, а отже, усвідомленість. Процес категоризації можна спостерігати на всіх рівнях пізнання: від сприйняття до осмислення. Як правило, категоризація здійснюється автоматично, несвідомо. Завдяки їй відбувається своєрідна «когнітивна економія», яка полегшує людині прийняття нової інформації [3, с. 24]. 
Отже, категоризація здійснюється на різних рівнях плинності людського досвіду й переробки інформації: психологічному, мовному, логічному, культурному тощо. Результатом категоризації на кожному із рівнів стають різні когнітивні утворення: поняття, або концепти; когнітивні схеми; мовні та культурні категорії тощо. Як писав Б. Уорф, ми членуємо світ, організовуємо його у поняття і розподіляємо значення так, а не інак, переважно тому, що ми учасники угоди, яка передбачає таку систематизацію. Ця угода має силу для певного мовного колективу і закріплена у системі моделей нашої мови [1, с. 28]. Саме через мову людина залучається до основних категорій культури.

Когнітивна діяльність людства призвела до формування пізнавальних категорій. Носії мови, узагальнюючи ситуації сприйняття, уявлення, мислення, комунікації, дії, втілюють їх у формі пізнавальної категоріальної сітки, своєрідного каркасу. Причому у текстах різних функціональних стилів і прагматичних спрямованостей такий каркас має різні опорні категорії. Але комплекс когнітивних категорій, які відбивають процес пізнання об'єктів дійсності, є обов'язковим, бо сприяють засвоєнню нової інформації.

Будь-яке пізнання розпочинається 3 дослідження його якісної сторони, а вже потім - кількісної і значно пізніше переходить до його оцінки. Дослідники переконують, що усвідомлення людиною навколишнього світу i себе у цьому світі шляхом пізнавальної діяльності відбувалося на початковому етапі раціонально-примітивним способом - за допомогою органів чуття [6]. Це і є свідченням того, що такі категорії пізнання як кількість, оцінка, час, простір та інші виникли на порівняно високому ступені розвитку людства. Відповідно, їм передував період якісного пізнання, що зумовлювався потребою людини оцінити предмет чи явище шляхом розпізнавання його визначальних рис. На першому місці, звичайно, такими рисами були виразні, унікальні ознаки, які пізніше у філософії здобули назву атрибутів [6]. Атрибути - це невіддільні ознаки, які характеризують предмет чи явище, i вони не можуть бути випадковими чи змінними. Отже, категорія тексту, i тексту документа також, обов'язково передає якісну характеристику дійсності. У документознавстві, на стику якого виникла документна лінгвістика, ми називаємо атрибутивність як одну $з$ основних властивостей документа, а серед категорій тексту документа іiї випускаємо. Чому? Можливо, тільки тому, що ії не описав I. Р. Гальперін, робота якого про текст як об'єкт лінгвістичного дослідження, написана ще у 1981p. і досі зберігає свою актуальність [4]. А саме його дослідження покладене в основу більшості посібників із документної лінгвістики.

Об'єктом вивчення документної лінгвістики як розділу мовознавства $є$ передусім текст. В основу дефініції текст у документній лінгвістиці покладено розуміння його як інформаційного самодостатнього мовленнєвого повідомлення з конкретною метою, скерованою за своїм задумом на свого адресата [2, с. 5]. Але текст документа своєрідний. Особливі умови документної комунікації, умови функціонування документного тексту накладають свій відбиток на його лінгвістичні параметри i, навпаки, вибір складного комплексу лінгвальних засобів як одиниць національних літературних мов впливає на технології створення документних об'єктів і на проведення документної комунікації. У рамках справочинства існують правила уніфікації, стандарти, інструкції та зразки. Умови, передбачені цими регулятивами, позначаються не тільки на формальних властивостях документів, а й на лінгвальному втіленні змістових положень документів. Інформативність у них - це не просто відображений в ньому фрагмент дійсності. Це також той аспект, в якому цей фрагмент розглядають. Одна справа тільки викликати відповідне ставлення до нього, інша - створити про нього загальне обгрунтоване уявлення, третя - глибоко розібратися в ньому, четверта - дати інструкції до конкретних дій. Прикладний стиль (саме так останнім часом іменують офіційно-діловий стиль) обслуговує тексти, розраховані на швидкість, мобільність, коли інформацію використовують для прийняття рішень. Цей стиль вимагає готового знання, підготовленого для того, щоб його «взяти і діяти». Такий текст повинен бути чітким, однозначним, відображати всі ознаки явища; 
легко сприйматися. Тому тексти, написані в прикладному стилі, максимально розчленовані - на пункти і підпункти, за схемами опису. Отже, категоріальний каркас таких текстів найміцніше тримається на основних категоріях - інформативності як змістовій категорії та дискретності і зв'язності - як структурній.

Особливі категорії тексту (інформативність, здатність тексту членуватися, зв'язність (когезія), континуум, автосемантичні відрізки тексту, ретроспекція, модальність, інтеграція, завершеність) на достатньому рівні розроблені у посібниках 3 документної лінгвістики М. Комової, Л. Чередник, В. Кубко, Г. Поберезської, І. Волинець, Л. Пізнюк [7]. Як правило, йдучи за I. Гальперіним, автори поділяють категорії тексту на дві групи: семантичну і структурну (змістові і формально-структурні у I. Гальперіна [4, с .4]). До першої відносять інформативність, комунікативність, цілісність, завершеність та ін., а до другої - інтеграцію, зв'язність, членованість, лінійність та ін.

В основі категоризації лежить правило враховувати такі риси об'єктів, які становлять категорію: 1 - властивості або критичні значення ознак об'єкта, який належить до цього класу; 2 - спосіб комбінування семантики ознак у процесі висновування про належність до класу на підставі цих властивостей; 3 вагомість різних ознак належності до класу для висновку на підставі цих властивостей; 4 - припустимі межі, за які не має виходити ознака об'єкта, що підтверджує належність до описуваного класу [3, с. 8].

Якість характеризується як один 3 пріоритетних щаблів у системі пізнання і поєднує в собі здатність вирізняти об'єкт з-поміж інших, характеризувати його зовнішні та внутрішні властивості, відносну стійкість об'єкта, вказувати на зміни, що відбуваються 3 ним та на тотожність його з однорідними об'єктами, давати цілісну характеристику функціональної єдності суттєвих властивостей об'єкта. Але про якість як категорію тексту досі не йшлося.

Як відомо, культурологи категорії культури поділяють на свої дві групи. До першої відносять онтологічні категорії, що виражають уявлення про найбільш загальні, універсальні атрибути навколишнього об'єктивного світу: простір, час, рух, зміни, властивість, якість, кількість, причина, наслідок, випадковість, закономірність і т. ін. Друга група категорій культури включає соціальні категорії, що характеризують людину і суспільство: праця, власність, влада, держава, свобода, справедливість, добро, совість, обов'язок і т. д. Обидві групи категорій тісно пов'язані, оскільки межа між онтологічними і соціальними категоріями відносна [9]. Вони вплетені в структуру мови, якою люди розмовляють, і охоплюють увесь культурний простір, пронизуючи ментальне поле культури подібно силовим лініям. Будь-яка конкретна культура мислить себе у притаманних їй опорних категоріях, без знання яких не зрозумієш іiї носія. Це загальні уявлення і установки, з яких виходять люди в сприйнятті і розумінні всього, про що мислять. 3 уявлень складається «категоріальний каркас» ментальності, властивий певній культурі. Цей «каркас» люди усвідомлюють зазвичай смутно і непевно, але все ж саме він обумовлює їхнє мислення: вони заповнюють його «смисловою начинкою», типовою «матрицею контенту». Отже, загальний аналіз категорій невіддільний від породжувальних ix пізнавальних процесів. Категоризація визначає таку базову для мови властивість, як здатність до узагальнення. I якщо визначати різницю між ознаками тексту та його категоріями (повертаючись до нез'ясованих позицій у лінгвістиці тексту), зважати варто саме на ці особливості - опорні (каркасні) когнітивні категорії.

Мовне вираження семантики категорії якості набагато ширше, ніж його змістове значення. Так, до диференціальних ознак змістової та мовної якісних категорій можна віднести суб'єктивність та об'єктивність як субкатегорії. Подібно рівневим одиницям мови, категорії тексту є знаковими утвореннями. План змісту такого знака - це та чи інша понятійна універсалія, спільна в цілому тексті семантика (наприклад, значення часу чи простору або у нашій тезі - значення якості, ознаки), а план вираження - точний добір різнорівневих мовних засобів, наприклад, у категорії якості це поєднання прикметників (збори трудового колективу; банківський звіт; органи місиевого самоврядування; документ: письмовий, 
рукописний, надрукований, зображувальний, графічний, аудіовізуальний), дієприкметників (зазначений пункт; контрольована ситуація, здобуті результати), порядкових числівників, займенників (цей, той, такий), означальних підрядних речень тощо.

Наукова новизна роботи виявлена в аналізі процесу категоризації дійсності, внаслідок якого мовні категорії тексту взагалі і документного зокрема постають як когнітивні утворення.

Висновки. Спостереження над змістовими і формальними категоріями та параметрами тексту документа свідчить про те, що цей текст має свій категоріальний каркас і $€$ осередком організованого, упорядкованого, запрограмованого акту комунікації в його прагматичній спрямованості. Категорія якості відіграє у ньому одну з основних функцій, надаючи документу чіткості, означеності. Перспективою подальших досліджень може стати категоріальна характеристика вторинних документів, де можна простежити вияв категорій у згорнутих текстах. Зокрема, цікавою на нашу думку, буде робота 3 категорією інформативності, оскільки стислий текст має підвищену інформативну насиченість у порівнянні з первинним повним варіантом.

\section{Список використаних джерел}

1. Бацевич Ф. С. Основи комунікативної лінгвістики. К. : Академія, 2004. 344 с.

2. Борковська І. П. Основні аспекти тексту ділових документів і методи текстового аналізу. Вісник НТУУ «КПІ». Філологія. Педагогіка: збірник наукових праць. 2013. Вип. 2. С. 5-12.

3. Брунер Дж. Психология познания. За пределами непосредственной информации. Пер. с англ. М. : Прогресс, 1977. 413 с.

4. Гальперин И. Р. Текст как объект лингвистического исследования. Изд. 4-е, стереотипное. М. : КомКнига, 2006. 144 с.

5. Кочан І. М. Лінгвістичний аналіз тексту: Навчальний посібник. 2-ге вид., перероб. і доп. К. : Знання, 2008. 423 с.

Осипчук В. М. Кореляція категорії якості у філософії та мові. URL: file://C:/Users/Admin/Downloads/ Nchnpu_10_2014_11_31.pdf (дата звернення: 24.11.2019).

П’ятничко Б. П. Статус документної лінгвістики в системі соціальних комунікацій. URL: file:///C:/ Users/Admin/Downloads/gileya_2013_76_47.pdf (дата звернення: 01.12.2019).

Сюта Г. Поняття тексту у некласичних мовознавчих парадигмах. Теоретична стилістика. Культура слова. №84, 2016. С.131-142.

Шепель Ю. О., Панченко О. І. Текст як об’єкт лінгвістики й основа спілкування. Лінгвістика. Лінгвокультурологія: Зб. наук. пр. за ред. д-ра філол. наук, академіка АН ВО України, проф. Ю. О. Шепеля. Дніпропетровський національний університет імені Олеся Гончара. URL: http://lingvodnu. com.ua/arxiv-nomeriv/lingvistika-lingvokulturologiya-tom-9-2016/tekst-yak-obyekt-lingvistiki-j-osnovaspilkuvannya/ (дата звернення: 29.11.2019).

\section{References}

1. Batsevych F.S. (2004). Fundamentals of Communicative Linguistics. Kyiv: Akademiia, 344 [in Ukrainian].

2. Borkovska I.P.(2013). Basic aspects of the text of business documents and methods of text analysis. Bulletin of NTUU «KPI». Filolohiia. Pedahohika: a collection of scientific works, 2, 5-12 [in Ukrainian].

3. Bruner J. (1977). Psychology of knowledge. Beyond direct information. Trans. with English. Moscow: Progress, 413 [in Russian].

4. Galperin I. R. (2006). Text as object of linguistic research. Ed. 4 , stereotyped. Moscow : KomKniga, 144 [in Russian].

5. Kochan I.M. (2008). Linguistic text analysis:. Kyiv: Znannya, 423 [in Ukrainian].

Piatnychko B.P. (2013). Status of documentary linguistics in the social communication system. Retrieved from: file:///C:/Users/Admin/Downloads/gileya_2013_76_47.pdf [in Ukrainian].

Osypchuk V.M. (2014). Coreliness categories of philosophy and language Retrieved from: file:///C:/ Users/Admin/Downloads/Nchnpu 102014 11 31.pdf [in Ukrainian].

Syuta H. (2016). Concept of text in non-classical movative paradigms. Theoretical stylistic. The culture 